American Journal of Computer Engineering
(AJCE)

\title{
The Impact of OTT Services in Nigeria: Regulators, Operators and Customers Perspective
}

\author{
Damilola Fowora*, Oludele Awodele, Olakunle Olayinka and Oyebode Aduragbemi \\ Department of Computer Science, Babcock University, Nigeria
}

\begin{abstract}
Advancement in the field of Information Communication Technology (ICT) has led to creation of new technologies, one of such *Correspondence to Author: is Over-The-Top technology. This new technology offers lowDamilola Fowora cost delivery of digital information content and services which Department of Computer Science includes VolP services, instant messaging services and so on to consumers. The Over-The-Top services do not have a network system of their own but instead rely on of telecommunication operator networks and other Internet Service providers for the delivery of their services, without any policy or lease agreement with these operators. This work focuses on considering the perspectives of the regulatory board, the telecommunication operators and the consumer has it relates to this technology. We also analyse the impact of the Over the Top technology has on the Nigerian economy also.

Babcock University, Nigeria

How to cite this article:

Damilola Fowora, Oludele Awodele, Olakunle Olayinka and Oyebode Aduragbemi. The Impact of OTT Services in Nigeria: Regulators, Operators and Customers Perspective. American Journal of Computer Engineering, 2018; 1:1.
\end{abstract}

Keywords: Over-The-Top, Regulators, Nigeria, Telecommunication Operator, Consumer

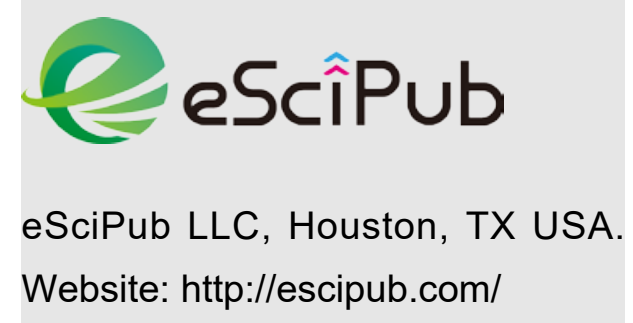




\section{Introduction}

The field of telecommunications has indeed grown over the past decade from the first generation analog cellular networks to the fourth-generation digital networks with data rates of up to $10 \mathrm{Gbs}$ at the downlink alone which is built on the internet protocol (Nortel, 2008). These advancements have brought about a new age of fast, cheap and efficient digital communication. The access to higher speeds of data transfer has led to the development of other modes of digital communication such as OverThe-Top (OTT) services which offers direct delivery of content directly to the consumer.

The ever-growing field of mobile telecommunication has evolved and various new technologies keep emerging. Today, there are so many ways to pass information or content from source to consumer creating a very competitive market. Over-The-Top services refers to the delivery of content to consumer via a carrier service or mobile operator without the carrier service itself being part of the planning, marketing, monitoring and regulating the content. Also, no financial or revenue agreement is made between the Over-The-Top (OTT) service providers and the carrier service. The carrier service acts simply as a medium for the delivery of content.

Communication is a vital part of any growing economy and it is also integral to the technological advancements, Nigeria is not an exemption. With a population of 195 million people (Worldometers, 2018), about 145 million have active GSM lines (NCC, 2018) which is over 74 percent of her citizens engaging in mobile digital communication. Mobile telephony in the country has gone a long way after its introduction to the Nigerian economy in August of 2001 with Econet and MTN being the first set of mobile operators in the nation (The Nigerian Voice, 2011). The impact of mobile telephony can not be under estimated, as at 2016 the industry was worth about 32 billion dollars (Vanguard Nigeria, 2016), contributing greatly to the gross domestic profit in the nation.

\section{Over-The-Top Architecture}

The Over-The-Top service provider provides service or content and also offer Information Communication Technology services but does not operate a network system and it has no ties to any telecommunication or network service operator (TRAI, 2015). The Over-The-Top service architecture rely on the global internet itself and gains network speeds in other to deliver content to consumers, hence it goes "over-the-top" of telecom service provider's network. Content and services provided with Over-The-Top are typically tailored towards media and communications at free or lower cost rates as compared to when the same services are delivered using the traditional network delivery process.

Over-The-Top service providers can access their consumers using two different ways. As seen in figure 1, Over-The-Top service providers can ride on top of the telecom service provider's network system without having any financial, policy or lease agreement with the telecom services. Using the method, the telecom service provider will be viewed as an Internet Service Provider providing internet connectivity and also bandwidth for the Over-The-Top applications. Also, another method for the Over-The-Top service providers to reach the consumers would also be to ride on top of bandwidth which is provided by Wireless Fidelity (Wi-Fi) operators. Both these methods exempt the Over-The-Top service providers from any financial implications to the use of these network services. Some common examples of applications that employ Over-The-Top services include:

1. Skype

2. WhtasApp

3. Facebook

4. Twitter

5. Instagram

6. Youtube etc.

Table 1 show some common applications of Over the Top applications, these applications are among the top used in the world today with over 2.46 billion subscribers combined (Statista, 
2018). With a world population of around 7.6 in the age of $5^{\text {th }}$ generation networks which billion people, the Over-The-Top subscriber is offers faster and cheaper data rates to about 32 percent of the total world population consumers (Internet World Stats, 2017).

and this is expected to grow as the world ushers

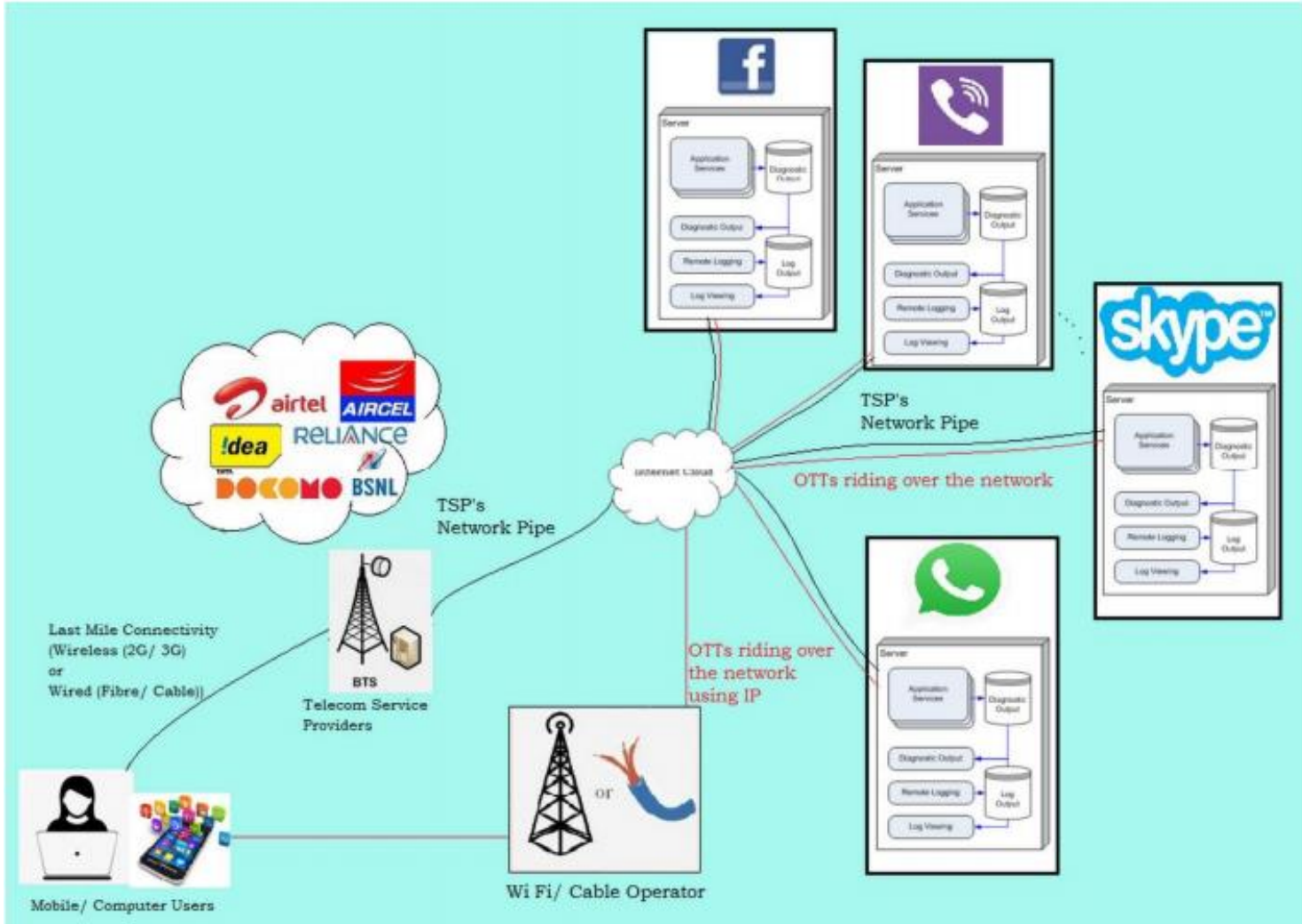

Figure 1: Over-The-Top Integration with Telecom Service Provider and other Service Providers (Source: (TRAI, 2015)

\begin{tabular}{|c|c|c|}
\hline OTT video & Skype & $\begin{array}{l}\text { - } 300 \text { million users (2013) } \\
\text { - Allows for free voice/video Skype to Skype calling } \\
\text { - Enable calling to Plain Old Telephone Service (POTS) via Skype-out service }\end{array}$ \\
\hline $\begin{array}{c}\text { OTT } \\
\text { messaging }\end{array}$ & WhatsApp & $\begin{array}{l}\text { - } \quad \text { Top selling app in } 47 \text { countries } \\
\text { - } \quad \text { Processing } 27 \text { billion messages daily (June 2013) } \\
\text { - } 300 \text { million active users (May 2013) } \\
\text { - } \quad \text { Available on all Smartphone platforms }\end{array}$ \\
\hline OTT media & $\begin{array}{l}\text { DETFLIXX } \\
\text { Netflix }\end{array}$ & $\begin{array}{l}\text { - } \quad \text { Curated/studio programming } \\
\text { - } 40 \text { million subscribers (May 2013) } \\
\text { - } \quad \text { Accounts for } 32.3 \% \text { of all US peak downstream fixed access traffic }\end{array}$ \\
\hline
\end{tabular}

Source: Detecon Consulting, 2014

Table 1: Examples of Over the Top Applications

One of the major reasons for the advancement of Over-The-Top services today is the fact that it has a dynamic architecture, all a consumer needs to access quality content is internet connectivity and another reason is also that it is cheap and at low cost of access to the consumer.

\section{Literature Review}

There are many organizations, institutions and also researchers that have studied the impact of 
Over the top services on various key entities in the telecommunication industry has a whole. Joshi et al (2015) studied the impact of Over the top services on telecommunication service providers. They made a global review on how Over the top services affects telecommunications services, detailing how revenue is lost to this service and it also shows how there has been a global shift in the consumer preference of this service to traditional telecommunication services.

This dramatic change in the preference of the consumer to be more drawn to the Over the top services than the traditional telecommunication services is not a new phenomenon. John Sladek (2006) wrote a paper detailing how Over the top services would be the new frontier for digital content delivery to the consumer. The work showed the future of digital communication and predicted that if the telecommunication operators are not careful, they would simply be used has a tool for the Over the top services providers to ride over and provide contents to the consumer.

Quoc Lai Nguyen (2016) did a literature review of Over the top related policy and regulatory issues. The work showed the complexity involved in regulating over the top services, due to the inabilities of regulators and also telecommunication operators to keep up with the dynamic and changing markets. The work gave examples of the failing attempts made by regulators in the United States to regulated over the top services and due to this unregulated technology, the telecommunication providers are losing their hold on the market, this can be said to be the case in Europe, where over the top services have a third of the telecommunication market share.

Baldry et al (2014) and Fedrick et all (2013) did quite similar works on over the top technology, detailing how it is creating a revolution in the world of telecommunication, they also make it know that if they are not regulated certain issues start to emerge. Issues of security, privacy were raised and also the only way to create a safe web space for the transfer of digital content would be regulations being imposed on over the top services. Suijata et al (2015) had a different view on the situation, they argued that regulations would create a monopolistic network environment where the telecommunication operators decide how digital contents are delivered and with the heavy monetary sanctions innovation wouldn't be possible on the part of the over the top service providers.

\section{Impact of Over-The-Top Applications on the Nigerian Economy}

In Nigeria today, the Nigerian Communications Commission (NCC) is an independent regulatory board that regulates the activities that occur in her telecommunications industry (NCC, 2018). The Commission is tasked with creating a conducive environment for the operations of telecommunications operators while ensuring adequate Quality of Service to its consumers throughout the country. The Nigerian Communications Commission (NCC) regulates digital technology in the country and with the advent of Over-The-Top services which brings about exciting prospects, certain issues start to emerge.

As at 2017, the National Bureau of Statistics (NBS) has stated that the telecommunications sector contributes over I.385 billion naira to the Gross Domestic Product (GPD) of the nation which is over one quarter of the total Gross Domestic Product (GPD) of the nation (Gabriel, 2016) this has a huge impact on the Nigerian economy. Also, job creation is also on the rise, as digital communication opens a new frontier when it comes business creation. Over the top applications have created a source of employment and a source of income for many individuals. Businesses are often time built on Over the top applications, applications such has Facebook, Twitter, Jumia, Konga and so on are means in which business is conducted, over 12.2 billion dollars was made through Facebook in the year 2015 and this is vastly due to the popularity of Over the top applications and this 
too has positively impacted the economy (Frommer, 2015).

Figure 2 gives a general overview of money supply in the nation, we see a steady increase in the Credit to Private Sector in the nation, the telecommunication industry makes up a vast portion of the private sector in the nation and we see huge financial resources being deposited into that sector.

The various telecommunications operators in the country are vastly privately controlled and operate with certain degree of anonymity, provided they follow guidelines as specified by the Nigerian Communications Commission (NCC), one of such is ensuring that all Subscriber Identity Module (SIM) card is registered to a specific user. With the anonymity these operators have, they can bill users how they want and they decide the various tariff plans for users without ny input from the Nigerian Communications Commission (NCC). Since, there are also other telecommunication operators offering the same service, the cost for services on these telecommunication operators stay within an affordable range.

With the advent of Over-The-Top services, certain issues start to emerge, the consumers can have access to quality information service content at a much cheaper rate than the telecommunication network can keep up with Over-The-Top services has greatly impacted the telecommunication industry in this country, the

regulators, operators and also the consumer have all been affected by this new technology and the question everyone is asking is should these OTT services be regulated or not. Currently they are not regulated and since they have no financial or lease agreement with the telecommunication operators, they might eventually drive them out of business since the OTT services can provide the same content as the telecommunication operators at much more cheaper rates.

This affects the industry greatly and the Nigerian economy has a whole. Telecommunication operators in Nigeria lost about 26-billion-naira voice calls revenue in the year 2017 due to the apparent decline of subscribers to use their services to make phone calls (Adaramola, 2018). Over-The-Top services was attributed as the cause of these loss, because they offer cheaper rates of cellular communication. Using Globacom Limited Telecommunications as an example, they offer about 12.5 Gigabytes of data for just two thousand five hundred $(2,500)$ naira, with this amount of data users can make calls on Over-The-Top services for thousands of hours to anyone across the world no matter the geographical location without any additional charges for international or local calls. If the same two thousand five hundred $(2,500)$ naira was used on calls alone the users might have about two to three hours of voice calls and when international numbers are dialled, the user might have about an hour of voice calls. The users would tend to save money and go for the cheaper option of the two and these would lead to losses for the telecommunication operators and the economy has a whole.

Considering not only the financial implications of having an unregulated Over-The-Top service offering content to consumers, issues of national security also arises. Over-The-Top services offer services that are encrypted and offers protection for consumers to remain completely anonymous and the content they share completely discrete. A typical example of these is messages sent with WhatsApp are so encrypted that it is extremely difficult for WhatsApp to in fact view them and prevents governments agencies from view them too (Griffin, 2016). Also, law enforcement agencies cannot obtain records from these Over-The-Top service providers to be used in criminal investigation. The privacy enjoyed by consumers can also be used to mask criminal activity and these possess a serious security threat to the nation (Adebayo, 2017).

\section{Regulators Perspective on Over-The-Top Services}


The effect of Over-The-Top services on the nation cannot be over emphasised and it raises more questions, one of such questions is should Over-The-Top services be regulated or not. In Nigeria, the executive chairman of the Nigerian Communications Commission (NCC), Prof. U.G Danbatta has announced to the public that the Nigerian Communications Commission (NCC) will take a neutral position on the matter. $\mathrm{He}$ made it clear that the Commission will not regulate Over-The-Top services and they are making it known to the public to take advantage of these services since they are very much affordable (Ekekwe, 2017). Nigeria is currently tending towards capitalist market where privately-owned institutions perform business and control their own markets and with competition from various other institutions offering the same service or content, the cost to the consumer is kept at a minimum. Due to this capitalist notion, the Commission would not want to disrupt this balance even if it bankrupts the telecommunication operators. The Commission has urged the telecommunication operators to be more innovative and basically find a way round this issue.

\begin{tabular}{|c|c|c|c|c|c|}
\hline \multirow{2}{*}{ Year } & \multirow{2}{*}{$\begin{array}{c}\text { Money Supply } \\
\left(\mathrm{M}_{2}\right) \\
\left(\mathrm{N}^{\prime} \text { Billion }\right) \\
\end{array}$} & \multirow{2}{*}{$\begin{array}{l}\text { Credit to Private } \\
\text { Sector }^{2} \text { (CPS) } \\
\left(N^{\prime} \text { Billion) }\right.\end{array}$} & \multirow{2}{*}{$\begin{array}{l}\text { GDP at Current } \\
\text { Basic Prices } \\
\text { (N' Billion) } \\
\end{array}$} & \multicolumn{2}{|c|}{ Financial Deepening } \\
\hline & & & & $\left(\mathrm{M}_{2} / \mathrm{GDP}\right)(\%)$ & (CPS/GDP) ( $\%)$ \\
\hline 2005 & $2,637.91$ & $1,838.39$ & $22,269.98$ & 11.8 & 8.3 \\
\hline 2006 & 3.797 .91 & $2,290.62$ & $28,662.47$ & 13.3 & 8.0 \\
\hline 2007 & $5,127.40$ & $3,680.09$ & $32,995.38$ & 15.5 & 11.2 \\
\hline 2008 & $8,008.20$ & $6,941.38$ & $39,157.88$ & 20.5 & 17.7 \\
\hline 2009 & $9,411.11$ & $9,147.42$ & $44,285.56$ & 21.3 & 20.7 \\
\hline 2010 & $11,034.94$ & $10,157.02$ & $54,612.26$ & 20.2 & 18.6 \\
\hline 2011 & $12,172.49$ & $10,660.07$ & $62,980.40$ & 19.3 & 16.9 \\
\hline 2012 & $13,895.39$ & $14,649.28$ & 71.713 .94 & 19.4 & 20.4 \\
\hline 2013 & $15,160.29$ & $15,751.84$ & $80,092.56$ & 18.9 & 19.7 \\
\hline 2014 & 17.679 .29 & $17,129.68$ & $89,043.62$ & 19.9 & 19.2 \\
\hline $2015^{1}$ & $18,901.30$ & $18,675.47$ & $94,144.96$ & 20.1 & 19.8 \\
\hline $2016^{3}$ & $21,607.68$ & $21,082.72$ & $101,489.49$ & 21.3 & 20.8 \\
\hline
\end{tabular}

Figure 2: Statistical Bulletin: Financial Statistics (Source: CBN(2016))

Table 1: OTT Applications Effect on Network Operators

\begin{tabular}{|c|c|c|c|c|}
\hline OTT & Examples & $\begin{array}{c}\text { Minimum Speed Req. } \\
\text { for Good Quality } \\
\text { Service }\end{array}$ & $\begin{array}{l}\text { Challenge for the } \\
\text { Network Operator }\end{array}$ & $\begin{array}{l}\text { Implication for the } \\
\text { Network Operator }\end{array}$ \\
\hline $\begin{array}{c}\text { Messaging } \\
\text { and Voice } \\
\text { Services } \\
\text { (Communication } \\
\text { Services) }\end{array}$ & $\begin{array}{l}\text { VoIP, Skype, Chat } \\
\text { with and without } \\
\text { video, Gmail, } \\
\text { WhatsApp, Wechat, } \\
\text { Line, Viber }\end{array}$ & $<$ lMBps & $\begin{array}{l}\text { Fixed and Mobile } \\
\text { telephony } \\
\text { substitute, SMS } \\
\text { substitute }\end{array}$ & $\begin{array}{l}\text { Competition, Loss } \\
\text { of value of } \\
\text { traditional } \\
\text { services offered }\end{array}$ \\
\hline $\begin{array}{l}\text { Application } \\
\text { eco-systems }\end{array}$ & $\begin{array}{c}\text { Social networks, } \\
\text { Facebook, Linkedin, } \\
\text { Twitter, Instagram, } \\
\text { WeChat, various } \\
\text { ecommerce apps } \\
\text { including mpayments, } \\
\text { mwallets- Amazon, } \\
\text { Flipcart, Snapdeal } \\
\text { Alibaba }\end{array}$ & $<$ IMBps & $\begin{array}{c}\text { Another medium } \\
\text { for } \\
\text { communications } \\
\text { (In case of ecommerce } \\
\text { apps, } \\
\text { it is another } \\
\text { market place) }\end{array}$ & $\begin{array}{c}\text { Competition, } \\
\text { Loss of revenue of } \\
\text { traditional } \\
\text { services offered. } \\
\text { (In case of ecommerce } \\
\text { apps, } \\
\text { loss of revenue to } \\
\text { existing brick and } \\
\text { mortar } \\
\text { establishments) }\end{array}$ \\
\hline Content & $\begin{array}{c}\text { OTT-TV, OTT Video, } \\
\text { streaming and video } \\
\text { on demand(VoD), } \\
\text { Netflix, Netmovies, } \\
\text { Hulu, Cuevana TV, } \\
\text { Youtube }\end{array}$ & 4-10 MBps & Substituting TV & $\begin{array}{c}\text { Not in direct } \\
\text { competition/ } \\
\text { Loss of audience } \\
\text { (hence } \\
\text { advertising) for } \\
\text { traditional TV } \\
\text { services }\end{array}$ \\
\hline
\end{tabular}


There are numerous reasons why Over-The-Top services remain unregulated, one of such is the complexity involved in the nature of Over-TheTop services themselves. Regulatory process has not been able to keep up with the fast developments of these services (Nguyen, 2016). An instance of these can be found in the US, Federal Communications Commission (FCC) has attempted to regulate Over-The-Top services and they have been twice been overturned by the courts, the overturn was due to the uncertainty on how the Federal Communications Commission (FCC) would intervene and oversee the relationship between telecommunication network operators. The situation in Europe is a lot more worse as telecommunication network operators loss about a third of the market to Over-The-Top services (Global Stats, 2018).

The Commission decision to remain neutral as been a topic of discussion between the Nigerian Communications Commission (NCC) and the telecommunication operators that feel let down by them, but the Commission still stands on the premise that the consumer is the one left with the choice to choose and forcing them would not be the best strategy so they remain neutral.

the Over-The-Top services and the

\begin{tabular}{|c|c|c|c|}
\hline Country & & Approach & Implications OTT \\
\hline China & $\star$ & $\begin{array}{l}\text { VolP is considered a basic service, reserved } \\
\text { for duly licensed operators }\end{array}$ & $\begin{array}{l}\text { OTTS usually blocked if they are not } \\
\text { allowed by the regulator. }\end{array}$ \\
\hline France & & $\begin{array}{l}\text { Ongoing investigation - OTT (Skype in this case) } \\
\text { could be classified as an operator, in which case it } \\
\text { would be subject to the same rules as the other } \\
\text { operators. }\end{array}$ & $\begin{array}{l}\text { Symmetric regulation for OTTS that offer } \\
\text { VolP. }\end{array}$ \\
\hline South Korea & & Internet connection is neutral but with flexibility. & $\begin{array}{l}\text { Operators can set a price for services } \\
\text { dedicated to premium users of OTT } \\
\text { (premium payable by the costumer). }\end{array}$ \\
\hline United Kingdom & 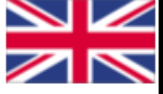 & $\begin{array}{l}\text { The differentiation of service and traffic is } \\
\text { accepted. }\end{array}$ & $\begin{array}{l}\text { Shapping is accepted if there is no } \\
\text { partnership with OTT. }\end{array}$ \\
\hline Germany & & All VolP providers are subject to the same rules. & $\begin{array}{l}\text { Symmetric regulation to OTTS that offer } \\
\text { VolP. }\end{array}$ \\
\hline UAE & & The VolP service offering is subject to license & $\begin{array}{l}\text { OTT services are blocked in the United } \\
\text { Arab Emirates }\end{array}$ \\
\hline
\end{tabular}

Table 2: Shows some nations in which net neutrality laws are in effect. Source: (Adebayo, 2017)

Net neutrality or internet neutrality which is the absence of discrimination of any type on the transmission of digital content over the internet also plays a significate role in ensuring that regulatory board in Nigeria stay neutral on this position. Net neutrality offers protection to investors and also the consumers, ensuring that that they are not overcharged for services and contents and also that investors can be allowed to be innovative without being held back with lease fees and policy agreements. In Nigeria today, there are no net neutrality laws (NCC, 2018), although one can argue that this leads to a more competitive market, Table 2 shows some nations in which net neutrality laws are in effect.

\section{Telecommunication Operators Perspective on Over-The-Top Services}

Nigerians spend a total of about 197 billion naira on a monthly basics on internet usage (BusinessNews Staff, 2017), the total sum accumulated by the telecommunications operators at the end of a financial year is high based on the number of Nigerians that subscribe to the internet for digital contents. This high increase in these figures can be attributed to the high use of Over the Top applications that is currently sweeping the nations, this achievement is also recognized by the International Telecommunications Union (ITU) (NCC, 2018) (BusinessNews Staff, 2017), which 
has referred to the Nigerian telecommunication industry as among one of the world's fastgrowing telecoms industry. These is also a way in which Over the Top applications has proved to be beneficial to the telecommunication operator, but considering the losses these telecommunication operators suffer in other areas of their operations, they call for regulating Over the Top applications.
The telecommunications operators are currently losing revenue to these Over-The-Top services and applications. A text message sent via Facebook is money lost that could have been gained through the use of Short Messaging Service (SMS), a call made via Skype is money lost also.

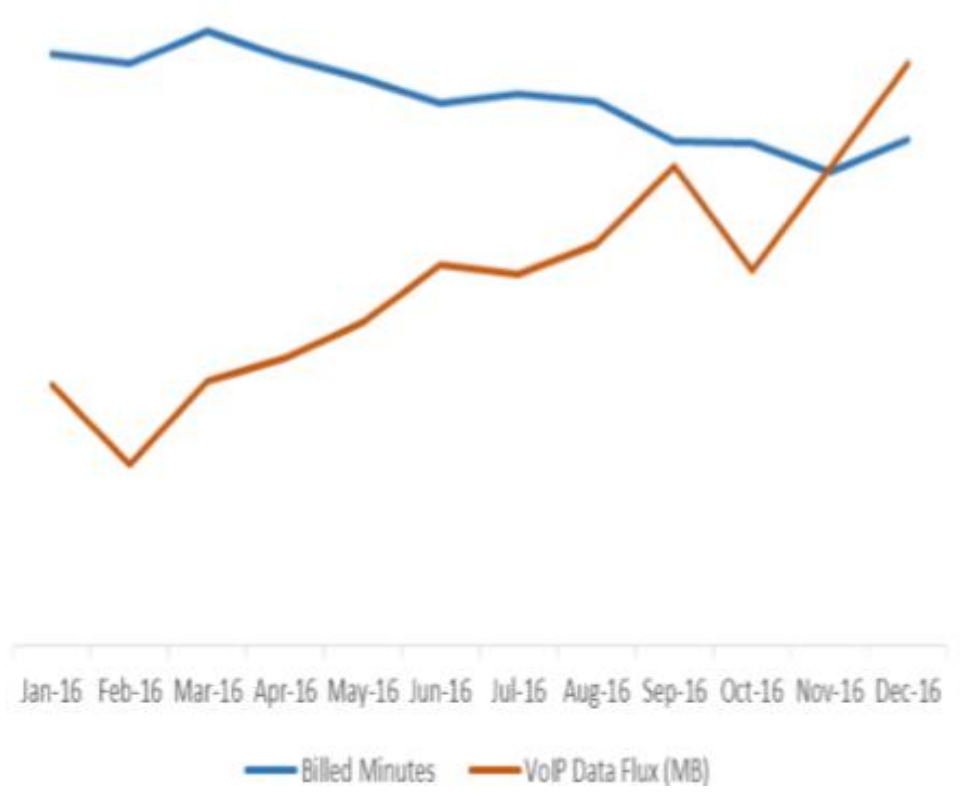

Figure 2: Showing the Decline of Billed Calls and the Rise of VolP Calls (Source: (Adebayo, 2017))

The telecommunications operators are experiencing significant losses in revenue to applications VolP services such Skype, WhatsApp and so on as shown in Figure 2 and Figure 3. The operators cannot match the OverThe-Top services in terms of cost and are left to find other ways to innovate and encourage the end users to use their platforms, one of such methods is offering the end users special bundles to encourage them to patronize their services like offering free call and free texts after a certain amount of money is loaded. The telecommunications operators are advocating for relegations been placed on the Over-TheTop services which would ensure a levelled business field for both the Over-The-Top services and the network operators. Some countries are currently regulating the Over-The-
Top services in their nations for example in China, Over-The-Top services are blocked if they are not licenced by regulators, in South Korea the operators set prices for Over-The-Top services. Some nations do not even bother to regulate these Over-The-Top services, they ban them out rightly, an example of this would be the United Arab Emirates. The regulators today have no plans to regulate the Over-The-Top services and the operators are left to figure out a way to continue making money and stay in business.

\section{Consumer Perspective on Over-The-Top Services}

The Nigerian market today is highly competitive, quality of service is very paramount to the consumer. The telecommunication operators are always looking for creative ways to get 
subscribers hook to their network services, operators offer services such as caller tunes, airtime borrowing, free texts, free calling minutes and so on, all in the bid to capture a very dynamic customer base with a very dynamic demographic. Over-The-Top services give the consumer assess to content and services which are similar to what can be gotten from the telecommunication operators but at a cheaper rate. When considering the opportunity cost of making a call using VolP applications and using
Messaging Service (SMS), one would see that the opportunity cost is very high in favour of Over-The-Top services. A consumer would prefer to spend less for the same service being offered by the telecommunication operators. Over-The-Top services as helped the consumers to spend less for content and digital services, showing a change market dynamic. The telecommunication operators do not have as much monopoly over digital communication services as they use to and the consumer would

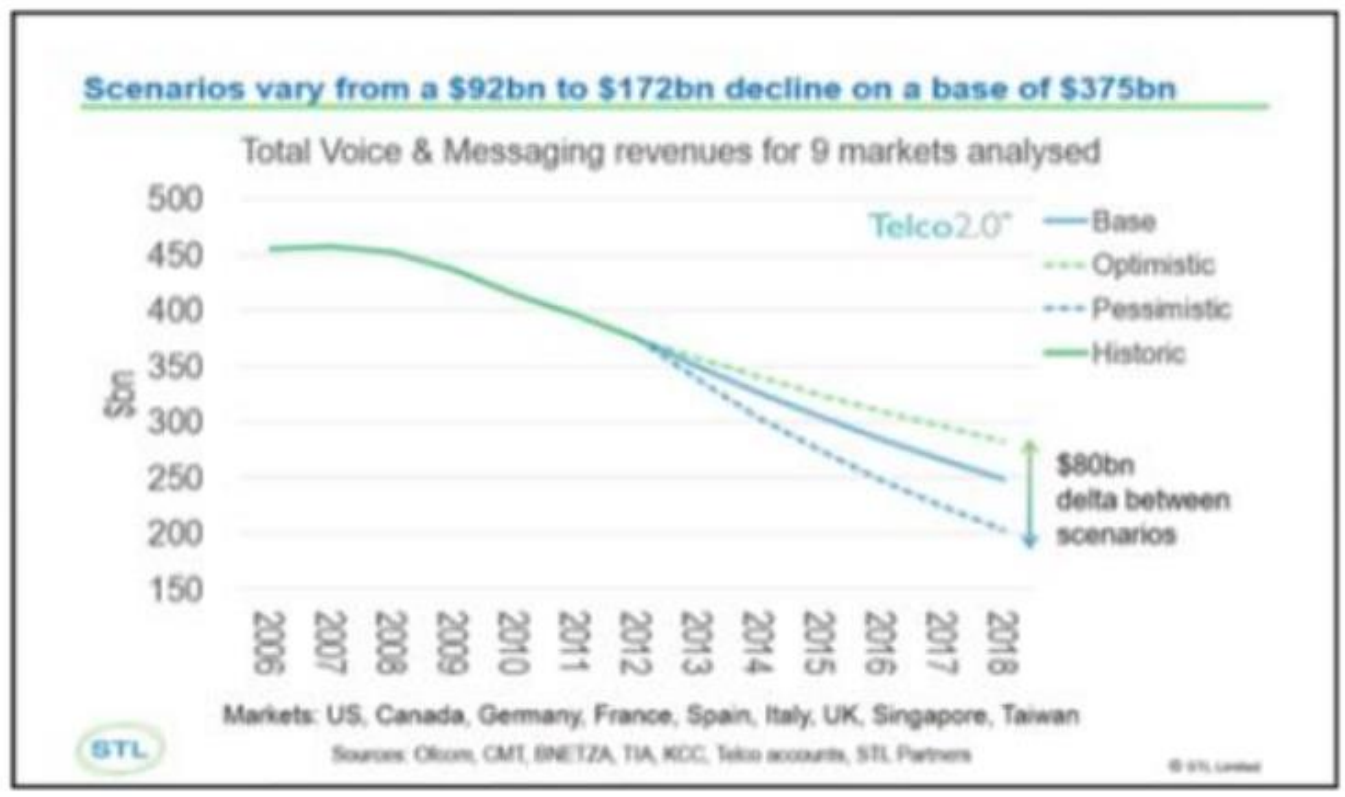

Source: STL, 2014

the telecommunication services or sending a prefer the to pay less. text using chat applications and via the Short

Figure 3: Showing Declining Revenues in Telecommunication Services

In Nigeria today about $87.37 \%$ of the overall 145 million that have active GSM lines use are active users on Facebook alone, and over $90 \%$ have their lines connected to WhatsApp (Global Stats, 2018). This shows how much these Over-the-top applications have been widely incorporated into the average Nigerian consumer everyday life. The ease and also the low cost of content delivery between consumers and also between content providers and consumers is maximized by the average consumer. This was the major contributing factor to the telecommunication losing over 26-billion-naira in revenue in the year 2017 (Adaramola, 2018). The average Nigerian would prefer to send a message using one of the
Over-the-top applications where the cost sending the message is basically insignificant as compared to paying 4 naira sending the same message via the short messaging service (SMS). The average WhatsApp user sends about 1,200 messages per month and also receives about 2,200 messages per month (Petronzio, 2014), it this same number of messages was sent over the short messaging service (SMS) a net average of 6,800 naira will be spent per month by each subscriber on just text alone. In a country in which the minimum wage is about 18,000 naira, paying about 6,800 naira on text alone is very high. The Nigerian 
consumer would prefer to use Over-the-top applications with its low-cost benefits.

\section{Conclusion}

Over-The-Top services has been a revolution to data communication, offering digital content at a low cost to the consumer. The low-cost delivery of digital content has left consumers preferring the optimize the advantages of using Over-TheTop services. Telecommunication operators References

1 Adaramola, Z. (2018, January 29). Telcos Lost N26bn Voice Calls Revenue in 2017. Retrieved from Daily Trust: https://www.dailytrust.com.ng/telcos-lost-n26bnvoice-calls-revenue-in-2017.html

2 Adebayo, G. (2017). "Over the Top" (OTT) Provision of Telecoms Services in Nigeria. Las Vagas: Associan of Licensed Telecommunications Operators in Nigeria.

3 BusinessNews Staff. (2017, September 1). Nigerians Spend N197bn Monthly on Internet Data. Retrieved from BusinessNews: http://businessnews.com.ng/2017/09/01/nigerian s-spend-n197bn-monthly-on-internet-data/

4 Ekekwe, N. (2017, June 24). How MTN, Glo, Etisalat, Airtel Will Solve OTT Problems And Boost Revenue In Nigeria. Retrieved from Tekedia: https://www.tekedia.com/how-mtn-gloetisalat-airtel-will-solve-ott-problems-and-boostrevenue-in-nigeria/

5 Frommer, D. (2015, January 28). Here's how much money you made for Facebook last year. Retrieved from Quartz: https://qz.com/335473/heres-how-much-moneyyou-made-for-facebook-last-year/

6 Gabriel, O. (2016, February 8). Telecommunications Spurs Growth in GDP. Retrieved from Vanguard: https://www.vanguardngr.com/2016/02/telecomm unications-spur-growth-in-gdp/

7 Global Stats. (2018, Febuary 2). Social Media Stats in Nigeria. Retrieved from StatCounter: http://gs.statcounter.com/social-mediastats/all/nigeria

8 Griffin, A. (2016, April 5). WhatsApp End-to-End Encryption. Retrieved from Independent www.independent.co.uk/life-style/gadgets-andtech/news/whatsapp-update-encryption-end-toend-messages-security-government-privacya6970101.html have recorded significant loss to Over-The-Top services, and these services ride over the telecommunication operators network without any policy or lease agreement. Regulators in the country have decided to remain technologically neutral and will not regulate the Over-The-Top service providers. Network operators are being pushed to be more innovative in other to stay relevant in this dynamic new market.

9 Internet World Stats. (2017, January 18). Internet World Stats. Retrieved from Internet World Stats, Usage and Population Satistics: http://www.internetworldstats.com/stats.htm

10 J. Sujata, S. S. (2015). Impact of Over the Top (OTT) Services on Telecom Service Providers. Indian Journal of Science and Technology, 8(4), $145-160$.

11 NCC. (2018, January 14). Subscriber Data. Retrieved from NCC: https://www.ncc.gov.ng/stakeholder/statisticsreports/subscriber-data

12 Nguyen, Q. L. (2016, July 22). A LITERATURE REVIEW OF OVER-THE-TOP. Dortmond, Germany: RHEIN-WAAL UNIVERSITY OF APPLIED SCIENCE.

13 Nortel. (2008). Long-Term Evolution (LTE): The vision beyond 3G. Nortel Networks, 2(5), 36-42.

14 Petronzio, M. (2014, Febuary 21). Average WhatsApp User Sends More Than 1,200 Messages Each Month. Retrieved from Mahable: https://mashable.com/2014/02/21/whatsappuser-chart/\#cMDj2KMw8Gqm

15 R. Friedrich, C. B. (2013). Enabling the OTT revolution \& How telecom operators can stake their claim,. Booz \& Company.

16 S. Baldry, M. S. (2014). The Rise Of OTT Players - What is the Appropriate Regulatory Response. Deutsche Telecom Group.

17 Statista. (2018, January 25). Number of Social Media Users Worldwide from 2010 to 2021 (in billions). Retrieved from Statista: https://www.statista.com/statistics/278414/numbe r-of-worldwide-social-network-users/

18 The Nigerian Voice. (2011, August 10). 10 Years of GSM Revolution. Retrieved from The Nigerian Voice:

https://www.thenigerianvoice.com/news/57892/1/ 10-years-of-gsm-revolution-in-nigeria.html 
Damilola Fowora et al., AJCE, 2018; 1:1

19 TRAI. (2015). Regulatory Framework for OverThe-Top (OTT) Services. India: Telecom Regulatory Authority of India.

20 Vanguard Nigeria. (2016, April 9). Nigeria's Telecoms Industry's Investment Profile Hits \$32bn, says Danbatta. Retrieved from Vanguard : https://www.vanguardngr.com/2016/04/nigerias- telecoms-industrys-investment-profile-hits-32bnsays-ncc-boss/

21 Worldometers. (2018, January 20). Nigerian Population. Retrieved from Worldometers: http://www.worldometers.info/worldpopulation/nigeria-population/

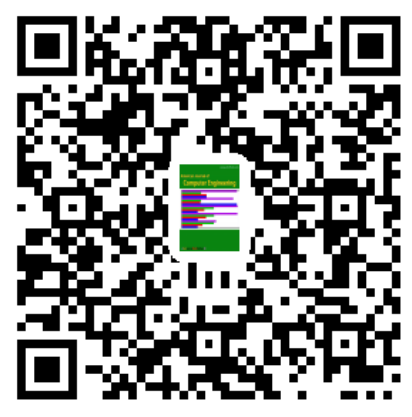

